\title{
Konfrontacja stylów narodowych imperiów ze stylami narodowymi terytoriów zależnych
}

\section{The confrontation of styles of national empires with the styles of dependent territories}

\section{Streszczenie}

Zjawisko stylów narodowych cechowały dwie właściwości: (1) proliferacja - mnożenie ich typów, paradoksalne, zważywszy na fakt, że styl narodowy określający tożsamość narodową powinien występować w jednej postaci oraz (2) konfrontacja (na ogół o charakterze pośrednim) stylów wykreowanych w krajach aspirujących do roli mocarstw ze stylami wykształconymi w krajach zależnych, które utraciły niepodległość. W pracy zestawiono neoromanizm - jeden z narodowych stylów niemieckich (którego głównym przedstawicielem był Franz Schwechten) - z polskim stylem nadwiślańskim, wykreowanym przez Jana Sasa-Zubrzyckiego. Drugim przywołanym przykładem jest polemika Stanisława Witkiewicza, twórcy stylu zakopiańskiego, z Edgarem Kovátsem usiłującym propagować eklektyczny „sposób zakopański”, zawierający pierwiastki architektury tyrolskiej.

Słowa kluczowe: styl narodowy w architekturze, styl nadwiślański, neoromanizm, architektura ludowa, Podhale

\begin{abstract}
The phenomenon of national styles is characterised by two properties: (1) proliferation - the combination of multiple styles, which is paradoxical given that the national style defining national identity should occur in one form; (2) the confrontation (usually of an indirect nature) between styles created in countries aspiring powers and styles created in dependent countries which lost their independence. The work juxtaposes neo-Romanism - one of the German national styles, whose main representative was Franz Schwechten - with the Polish Vistula style, created by Jan Sas-Zubrzycki. The second example cited is a comparison Stanisław Witkiewicz, the creator of the Zakopane style, with Edgar Kováts trying to promote the eclectic 'Zakopane way' containing elements of Tyrolean architecture.
\end{abstract}

Keywords: national style in architecture, Vistula style, neo-Romanism, folk architecture, Podhale 


\section{KONFRONTACJA Z OBCYMI STYLAMI NARODOWYMI}

Na ziemiach polskich w końcu XIX wieku i na przełomie XIX i XX wieku miał miejsce proces wykrystalizowania się szerokiego spektrum stylów narodowych. Najbardziej znany był i jest wykreowany przez Stanisława Witkiewicza styl zakopiański. Styl ów, jak wspomniano w rozdziale Styl zakopiański Stanisława Witkiewicza i jego differentia specifica ${ }^{1}$, odwoływał się do form architektury ludowej Podhala. Pozostałe style narodowe bazowały na formach architektury historycznej. Głównymi stylami narodowymi operującymi formami historycznymi były: styl wiślano-bałtycki (głównym teoretykiem i architektem wznoszącym budowle w stylu był Józef Pius Dziekoński), styl dworkowy oraz style nadwiślański i zygmuntowski. Dwa ostatnie zostały wykreowane i skodyfikowane przez działającego na ziemiach polskich pozostających pod ówczesnym zaborem austriackim Jana Sasa-Zubrzyckiego. Styl nadwiślański nawiązywał do gotyku, w stylu zygmuntowskim wyraźne były inspiracje formami renesansowymi.

W istnieniu tak szerokiego spektrum stylów narodowych tkwi oczywiście fundamentalna sprzeczność. Styl narodowy, mający określać tożsamość narodową, powinien funkcjonować w jednej obiektywnie określonej postaci. Koncepcja stylów narodowych była w dużej mierze konstruktem kulturowo-społecznym powstałym w określonych warunkach społeczno-politycznych.

Style narodowe były używane jako narzędzia dokumentowania i manifestowania pozycji imperialnej krajów pretendujących do rangi mocarstw jak wiktoriańska Wielka Brytania i bismarckowskie, a później wilhelmińskie Niemcy (zwłaszcza po zjednoczeniu w 1871 r.). W krajach tych powstały pierwsze budowle w stylach narodowych. Projektowanie budowli w stylu narodowym stało się również narzędziem przemocy symbolicznej wobec krajów czy narodów zależnych.

Na zasadzie reakcji powstawały (tam, gdzie było to możliwe) style narodowe krajów, a właściwie terytoriów zależnych. Celem projektowania budowli w stylu narodowym w tym wypadku było dążenie do kultywowania tradycji narodowych krajów, które utraciły niepodległość. Architektura poprzez w różny sposób wykształcone style narodowe stała się swego rodzaju polem konfrontacji.

W Niemczech poszukiwania stylu narodowego sięgają końca XVIII wieku. W ciągu kolejnych stu lat styl narodowy bywał utożsamiany z różnymi stylami z przeszłości. Kolejnymi stylami stawały się: neogotyk, neorenesans, neoromanizm (najwybitniejszym architektem działającym w tym stylu był Franz Schwechten), neobarok oraz Rundbogenstil (styl okrągło-łukowy, arkadowy).

Pierwszym chronologicznie niemieckim stylem narodowym stał się neogotyk. Dwa wydarzenia symbolicznie inicjują ów styl. W 1773 r. Johann Wolfgang Goethe wydaje artykuł Von deutscher Baukunst poświęcony katedrze w Strasburgu i jej architektowi Erwinowi von Steinbachowi. Artykuł jest apoteozą stylu gotyckiego w wersji niemieckiej. Zainteresowanie stylem gotyckim wywołują również prace badawcze i wykończeniowe przy katedrze 
w Kolonii. Katolicki charakter gotyckiej katedry w Kolonii w dobie rozwoju nacjonalizmu staje się przyczyną spadku zainteresowania neogotykiem i wszczęcia poszukiwań nowego stylu narodowego. Drugą przyczyną odwrotu od neogotyku staje się przeświadczenie na temat francuskiej proweniencji gotyku. Poszukiwania sięgają w głąb historii do coraz odleglejszych w czasie epok. W epoce Cesarstwa Niemieckiego (od 1871 r.) za narodowy styl niemiecki zostaje uznany neoromanizm.

Konfrontacja z próbami symbolicznego zawłaszczania przestrzeni miała miejsce również na terenie zaboru rosyjskiego. W Rosji wykształciły się style narodowe neorosyjski i neobizantyjski. W Warszawie wzniesiono na Placu Saskim sobór św. Aleksandra Newskiego (1894-1912). Projektantem świątyni był Leontij Benois. Świątynię o olbrzymich gabarytach (wysokość 75 m) wzniesiono na jednym z najbardziej reprezentacyjnych placów Warszawy, co było dodatkowym wyrazem zniewolenia ludności polskiej. Wystrój architektoniczny w sposób dosłowny powtarzał typowe rosyjskie cerkwie. Po odzyskaniu niepodległości sobór rozebrano.

\section{NIEMIECKI STYL NARODOWY - NEOROMANIZM. SYMBOLICZNE ZAWŁASZCZENIE PRZESTRZENI - DZIELNICA CESARSKA W POZNANIU}

Przykładem zawłaszczenia przestrzeni, „przemocy symbolicznej” w architekturze jest zaprojektowanie i realizacja Dzielnicy Cesarskiej w będącym pod zaborem pruskim Poznaniu na przełomie XIX i XX wieku. Pochodząca z roku 1903 koncepcja urbanistyczna jest dziełem wybitnego niemieckiego urbanisty Josepha Stübbena. Oficjalnym celem zaprojektowania dzielnicy były względy poprawy jakości przestrzennej i higienicznej miasta. Niezależnie od tych racjonalnych względów chodziło o nadanie Poznaniowi zdecydowanie niemieckiego (a nawet praniemieckiego) charakteru. Miasto uzyskało tytuł Rezydencjonalnego Miasta Poznania. Monumentalna zabudowa dzielnicy została wzniesiona wokół zachodniej części ulicy św. Marcin. Sama ulica została obramowana od północy budynkiem Zamku Cesarskiego (1905-1910), a od południa budynkiem Ziemstwa Kredytowego i Dyrekcji Poczty. Obydwa budynki zaprojektował wybitny architekt Franz Schwechten w niemieckim stylu narodowym - neoromańskim. Styl neoromański został wybrany jako nawiązujący do stylu romańskiego, wcześniejszego od gotyku i renesansu, które były inspiracjami dla pozostałych styli narodowych niemieckich. Uważany był za styl w pewnym sensie germański. Romanizm towarzyszył wczesnośredniowiecznej monarchii cesarzy z rodów Welfów i Hohenstaufów². Przy projekcie zamku osobistych wskazówek udzielał cesarz Wilhelm II. Prócz wymienionych budowli tworzących symboliczną „bramę” wjazdową od strony zachodniej (od strony Berlina, w miejscu wyburzonej Bramy Berlińskiej) w skład dzielnicy wchodziły m.in. Teatr Wielki, Akademia Królewska, Dom Ewangelicki, Komisja Kolonizacyjna.

Dzielnica zawłaszczała przestrzeń w dwojaki sposób. Pierwszy rodzaj zawłaszczenia przestrzeni związany był z funkcją - wzniesione budynki przeznaczone były dla władz, administracji 
i ludności niemieckiej. Dwie spośród budowli - zamek i budynek Komisji Kolonizacyjnej, w sposób szczególny podkreślały zniewolenie ludności polskiej i wykluczenie niepodległości. Drugim typem zawłaszczenia przestrzeni było zawłaszczenie symboliczne. Jak wspomniano, budynki Zamku Cesarskiego i Ziemstwa Kredytowego zostały przez Franza Schwechtena zaprojektowane w stylu neoromańskim, uważanym za jeden z narodowych styli niemieckich.

Franz Schwechten był autorem monumentalnego kościoła Kaiser-Wilhelm-Gedächtniskirche w Berlinie (1891-1895) wzniesionego w narodowym niemieckim stylu neoromańskim. Kościół ów wybudowano w reprezentacyjnym miejscu Berlina, przy bulwarze Kurfürstendamm. Budynek kościoła otaczała zabudowa mieszkaniowa i usługowa wzniesiona również w stylu neoromańskim. Na uwagę zasługiwały zwłaszcza nieistniejące już budynki autorstwa F. Schwechtena: Erstes Romanisches Haus przy Kurfürstendamm (1893-1896) oraz Neues Romanisches Haus przy Augusta-Viktoria-Platz, narożnik Kurfürstendamm (ok. 1900). Spośród innych budynków zaprojektowanych przez architekta w stylu neoromańskim warto wymienić: kościół św. Piotra i Pawła w Steinach w Turyngii (1899), wieżę Quistorpa w Szczecinie (1900-1904) i Anhalter Bahnhof w Berlinie (1841, nieistniejący). W stylu neoromańskim wzniesiono kościół ewangelicko-augsburski św. Mateusza (1909-1928) w Łodzi (w ówczesnym zaborze rosyjskim). Projektowali go Johannes Wende i Franz Schwechten.

Sylwetka Kaiser-Wilhelm-Gedächtniskirche wieńcząca kompozycyjnie bulwar Kurfürstendamm stała się jedną z dominant i ikon Berlina w okresie poprzedzającym I wojnę światową i w epoce międzywojennej. Podczas II wojny światowej w listopadzie 1943 roku kościół wraz z otaczającą zabudową został zbombardowany podczas wielkiego nalotu alianckiego. Po wojnie postanowiono nie odbudowywać kościoła ani otaczającej go zabudowy. Do zachowanej, częściowo zrujnowanej jednej z wież dobudowano nowoczesny budynek sakralny z charakterystycznymi przeszkleniami z luksfer. Wykreowano w ten sposób rodzaj monumentu stanowiącego memento - ostrzeżenie przed wojną i niebezpieczeństwami wynikającymi z rozwoju szowinizmu nacjonalistycznego. W miejscu kamienic w stylu neoromańskim, w zmienionym układzie urbanistycznym, wzniesiono modernistyczne, banalne pierzeje.

Kościół Kaiser-Wilhelm Gedächtniskirche wraz z sąsiadującymi pierzejami Kurfürstendamm tworzyły do 1943 r. jednolity stylistycznie zespół urbanistyczny (obecnie nieistniejący). Odcinek berlińskiej ulicy był bardzo podobny do fragmentu ul. św. Marcin w Poznaniu. Podróżny przyjeżdżający z Berlina pociągiem, wchodząc lub wjeżdżając do Poznania poprzez „bliźniaczą” przestrzeń neoromańskich budowli, mógł odnieść wrażenie, że przebywa w „małym Berlinie”.

W budynku Zamku Cesarskiego (i w pozostałych projektowanych przez siebie budynkach) Franz Schwechten posłużył się zbiorem środków formalnych związanych ze stylem neoromańskim jako niemieckim stylem narodowym:

1. Elementy bryły i kształtowanie elewacji zainspirowane architekturą pałacu cesarskiego - Palatium w Goslar (1219 r.) (zwłaszcza arkadowe okna na piętrze tzw. Kaiserhaus) oraz architekturą zamku Wartburg koło Eisenach ${ }^{3}$, a także architekturą romańskiego opactwa i kościoła benedyktyńskiego Maria Laach. 
2. Fasada kształtowana przy pomocy monumentalnej kamieniarki z dużych, jasnych piaskowcowych elementów.

3. Duże otwory okienne ukształtowane w postaci romańskich triforiów, czasem dwupoziomowe. Mniejsze otwory okienne zaprojektowano na ogół jako biforia.

4. Wieże zlokalizowane w narożnikach budynków, o wysokości nieznacznie przekraczającej wysokość budynku, wywołujące wrażenie zwartości i monumentalności.

5. Wieże wyższe jako dominanty: w Zamku Cesarskim wieża o wysokości 75 m (uszkodzona w czasie II wojny światowej - odbudowana do niższej wysokości), w Kaiser-Wilhelm Gedächtniskirche w Berlinie wieża o wysokości $113 \mathrm{~m}$.

6. Zaburzenia stylistyczne w Zamku Cesarskim: apartamenty cesarskie w kondygnacji piano nobile w wieży zamkowej oraz kaplica otrzymały wystrój w stylu neobizantyńskim; mała architektura - Fontanna Lwów w stylu orientalno-mauretańskim wzorowana na fontannie z Alhambry w Grenadzie.

7. Na obszarze zaboru pruskiego miały miejsce najostrzejsze spośród wszystkich zaborów działania polityczne zmierzające do zniewolenia i wynarodowienia. Działaniom tym towarzyszyły wspomniane wyżej działania przestrzenne głównie na terenie Poznania, polegające na symbolicznym zawłaszczaniu przestrzeni.

\section{STYL NADWIŚLAŃSKI SASA-ZUBRZYCKIEGO JAKO NAJWYBITNIEJSZY PRZYKŁAD POLSKIEGO STYLU NARODOWEGO BAZUJĄCEGO NA FORMACH HISTORYCZNYCH}

Działania te wywołały reakcję m.in. na terenie Galicji w zaborze austriackim. Był to obszar jedynego zaboru, w którym dzięki liberalnym warunkom autonomii galicyjskiej (po 1867 r.) taka polemika była możliwa. W piśmiennictwie związanym z teorią architektury pojawiły się liczne teksty o akcentach antyniemieckich. Szczególnie widoczne są akcenty antyniemieckie w dziele Jana Sasa-Zubrzyckiego Styl Nadwiślański. Architekt polemizuje z nazwą „styl wiślano-bałtycki" proponowaną według niego przez Niemców. Pisze we właściwym dla siebie barwnym i polemicznym stylu: „Jeżeli wedle Łepkowskiego »uczeni Niemcy odcień naszego stylu ostrołukowego wiślano-bałtyckim mianować nawykli« to mniej temu się dziwujemy, bo Niemcy od początku chcą sobie przypisać właściwości tego odcienia, jakoby to my od Krzyżaków je wzięli. - Nie jest to prawdą!". Następnie podkreśla we własnej definicji stylu nadwiślańskiego jego jednoznaczną rodzimość i „polskość”. Oczywiście w tym przypadku mamy również do czynienia z zawoalowanym atakiem na Józefa Piusa Dziekońskiego, głównego teoretyka stylu wiślano-bałtyckiego.

Jan Sas-Zubrzycki jest twórcą terminu i kodyfikacji zasad stylu nadwiślańskiego, najbardziej znanego stylu narodowego polskiego poza stylem zakopiańskim. W stylu tym zrealizował architekt największą ilość obiektów spośród architektów polskich tworzących w konwencji stylów narodowych. Były to głównie obiekty sakralne. Sas-Zubrzycki tworzył 
budowle o charakterystycznym, rozpoznawalnym wystroju. Fakty te predestynują jego twórczość do szerszego omówienia jako przykład dojrzałego stylu narodowego bazującego na formach historycznych. Zasady stylu nadwiślańskiego wyjaśnił w książce pt.: Styl nadwiślański jako odcień sztuki średniowiecznej w Polsce wydanej w roku 1910 w Krakowie ${ }^{5}$. Jan Sas-Zubrzycki jest również autorem monumentalnego cyklu Skarb architektury w Polsce obejmującego cztery tomy tablic rysunkowych dokumentujących zabytki wzniesione na ziemiach polskich oraz ich detale. Wartość cyklu jest nieoceniona, zwłaszcza że część z tych dzieł architektury już nie istnieje i rysunki stanowią jedno z niewielu świadectw ikonograficznych ich wyglądu.

Twórczość teoretyczna Jana Sasa-Zubrzyckiego jest amalgamatem rzetelnych informacji technicznych i historycznych, twierdzeń graniczących z mistyką, poglądów narodowych i słowiańskich (m.in. powołuje się na tom dzieł Mickiewicza wydany w serii Literatura słowiańska). Styl architekta jest zawiły, pełen dygresji, poetycki, graniczący czasem z grafomanią. Charakterystyczna jest pasja polemiczna i germanofobia.

Warto oddzielić fragmenty dotyczące kwestii kompozycyjnych i technicznych spośród kontrowersyjnych treści pism Sasa-Zubrzyckiego. Wyszczególniono siedem głównych właściwości gotyku nadwiślańskiego, które można „wypreparować” z jego zawiłego, poetyckiego tekstu. Wydało się rozsądnym zacytowanie w publikacji obszernych fragmentów oryginalnych sformułowań Sasa-Zubrzyckiego. Ukazują one jego retorykę pisarską, a jednocześnie potencjalne trudności, towarzyszące analizie jego tekstów. Lista owych siedmiu właściwości obejmuje następujące punkty ${ }^{6}$ :

1. Zasada zastąpienia (w porównaniu np. z katedrami francuskimi) systemu zewnętrznych łuków przyporowych systemem filarowo-skarpowym (tzw. krakowska szkoła filarowo-skarpowa). Sas-Zubrzycki zdecydowanie gloryfikuje zalety owego „narodowego” w jego mniemaniu systemu. Pisze w charakterystyczny dla siebie sposób: „Śmiemy twierdzić stanowczo, iż właśnie dla tej przyczyny, dla unikania łuków odpornych, przewyższyliśmy sztukę zachodu, nie w znaczeniu technicznem, ale pod względem estetycznym. Łęki odporne są co prawda znamienitym dowodem postępu konstrukcyjnego, posuniętego bezsprzecznie aż do zenitu biegłości i »opanowania materjału« - lecz co ważniejsza z punktu widzenia piękna kształtu nie zasługują wcale na uznanie!"7.

2. Zasada występowanie dwudziału na fasadach gotyckich (tzw. dwunałęcz); przejawiająca się w występowaniu wnęk i podziałów okiennych na dwie części. W taki sposób opisuje architekt ową zasadę dwunałęcza: „Prócz bowiem laski na osi założonej, staje się dla ostrołuku w Polsce niezmiernie charakterystycznym szczegółem ta wnęka o dwunałęczu, spoczywającem albo na słupku osiowym znowu, albo na lasce, lub wreszcie, po opuszczeniu słupka albo laski, na wsporniku. - To pole o dwóch nałęczach, czyli »dwunałęcze« jest znamieniem tak ważnem a tak rozpowszechnionem, że właściwie odgrywa główną rolę dekoracyjną w ukształtowaniu ścian wieżowych lub szczytów naszych"8. 
3. Zasada występowania sygnaturek na osi i na wierzchołku szczytu ponad prezbiterium. Opisuje ów element następująco: „Sygnaturki murowane na osi i na wierzchołku szczytu ponad częścią kapłańską kościoła założone, to jedna także z najważniejszych i najistotniejszych właściwości stylu nadwiślańskiego! Ta sama myśl, która wprowadziła laskę dwunałęcza na osi [...] , która wypełniała oś szczytu laską i sterczyną, [...] która trzymała się stale zwyczaju powtarzania dwunałęcza [...] - ta sama myśl zapragnęła silniej zaakcentować zwieńczenie szczytu kościoła w Polsce" ${ }^{\prime 9}$.

4. Budząca kontrowersje hipoteza wywodzenia proporcji z zasady tzw. trójkąta egipskiego, zwłaszcza przy kształtowaniu ścian szczytowych; (m.in. zasada liczb naturalnych 3, 4, 5, ale też i zasada samego trójkąta). Zasadę trójkąta egipskiego opisuje Jan Sas-Zubrzycki za Plutarchem: „Wedle Plutarka Egipcjanie symbolem wszechświata nazywali trójkąt najpiękniejszy. Trójkąt ten miał za podstawę bok o czterech częściach, wysokość pod kątem prostym wzniesioną o trzech częściach, skutkiem czego wypadała przeciwprostokątnia o pięciu częściach. Kwadrat obydwóch przyprostokątni równa się kwadratowi przeciwprostokątni"10.

5. Teza (kontrowersyjna) o zastosowaniu proporcji wywodzących się z trójkąta egipskiego w rzutach kościołów gotyckich polskich. Jednym z zastosowań zależności matematycznych trójkąta egipskiego było według architekta ustalenie proporcji rzutu poziomego kościołów, a także rzutów filarów międzynawowych: „Mając wszakże na razie mówić o układzie rzutów poziomych, musimy podnieść ciekawe właściwości tych filarów międzynawowych Szkoły Krakowskiej. Przedewszystkiem, z zadziwieniem niespodziewanem spotykamy się tutaj znowu w stosunku ich długości do ich szerokości z »prawem złotego cięcia «, czyli z zasadą trójkąta egipskiego"11.

6. Mistyczna, kontrowersyjna i zapewne błędna teza na temat „przechylenia osi prezbiterium” jako symbolu przechylenia głowy Chrystusa na krzyżu.: „Przechylenie n.p. osi części kapłańskiej (prezbiterjum) względnie »linji świętej« kościoła było symbolem przechylenia głowy Chrystusa na krzyżu. Prawda... wyraźnego a stałego przepisu na to nigdzie nie znajdujemy, wszelako nikt nie zaprzeczy, że nader częste przykłady, wszędzie występujące, są dowodem niezbitym, jak wielkie temu wyrazowi przypisywano znaczenie. U nas w Polsce dla symbolu tego większe może panowało poszanowanie jak gdzieindziej. Dokładne zebranie wzorów w tym kierunku przynosi ciekawe zestawienie. - Na razie wspomnieć pragniemy o trzech katedrach polskich w Krakowie, Gnieźnie i Poznaniu. - Wszystkie one stale trzymają się tej zasady, przechylenia osi części kapłańskiej"12.

7. Zasada wprowadzania w projektowanych kościołach elementów architektury romańskiej w dolnych partiach w celu uzyskania efektu „narastania” historycznego. Zasady owej architekt nie zawarł nigdzie w swoich pismach. Można ją odczytać, analizując strukturę kompozycyjną projektowanych i zrealizowanych przez niego kościołów. Owo „konstruowane" nawarstwianie jest stosowane bardzo konsekwentnie. 
Narastała również świadomość zagrożenia ze strony sztuki i kultury niemieckiej. Pisze Jan Sas-Zubrzycki w sposób dramatyczny w swoim Stylu Nadwiślańskim:

Stq̨d pochodzi omyłka nasza, żeśmy dotychczas nie przyszli wcale do wytworzenia pojęcia o odcieniu naszej architektury, bośmy zawsze poczynali od tego wyszukiwania podobieństwa i na tem podobieństwie kończyliśmy wywody ostatecznem twierdzeniem: - niema nic w naszej architekturze właściwego naszej sztuce - wszystko podobne do sztuki niemieckiej i koniec. Niemcy u nas wszystko wykonywali, dlatego wszystko niemieckie. - Tak wszyscy twierdzq i tak ciagle się powtarza ${ }^{13}$.

Pewnym paradoksem jest to, że architekt działał na terenie zaboru austriackiego, gdzie presja na wynarodowienie była stosunkowo łagodna. Obszar Polski, pomimo wielu lat podziału i zniewolenia przez państwa zaborcze nadal był w owych czasach postrzegany jako integralna całość. Sas-Zubrzycki dostrzegał zagrożenia dla polskiej architektury i w ogóle kultury jako całości ze strony niemieckiej. Warto dodać, że dodatkowym zagrożeniem był fakt odbywania studiów przez wielu polskich architektów, m.in. z terenu Austro-Węgier na niemieckich uczelniach. W nieoczekiwany sposób stał się on przyczyną powstawania wpływów kultury niemieckiej.

\section{SPÓR O KSZTAŁT STYLU ZAKOPIAŃSKIEGO MIĘDZY STANISŁAWEM WITKIEWICZEM I EDGAREM KOVÀTSEM}

Przykładem bezpośredniej konfrontacji pomiędzy stylami narodowymi był spór o kształt stylu zakopiańskiego pomiędzy Stanisławem Witkiewiczem i Edgarem Kovàtsem wraz z kadrą C.K. Szkoły Zawodowej Przemysłu Drzewnego w Zakopanem z drugiej strony. Dyrektorzy państwowej szkoły propagowali formy tyrolskie w architekturze i wzornictwie. Szkoła funkcjonowała w Zakopanem od roku 1878, w roku 1891 otrzymała nazwę C.K. Szkoła Zawodowa Przemysłu Drzewnego. Pierwszym dyrektorem był Franciszek Neužil. Początkowo rozpowszechniał on typowe formy tyrolskie, później dopuszczał asymilację form polskich. Jego kurs kontynuował Edgar Kovàts po przejęciu dyrekcji szkoły w roku 1896. W szkole w zasadzie nie wolno było tworzyć w stylu polskim góralskim.

Kovàts określał swój styl jako „sposób zakopański”. Polityka artystyczna prowadzona przez Szkołę i jej dyrektorów, aktywnie popierana przez władze w Wiedniu, stwarzała realne zagrożenie dla rodzimej, polskiej kultury. W roku 1887 wybudowano przy Krupówkach willę „Marya” (później nazwę zmieniono na „Poraj”) w stylu tyrolskim autorstwa architekta Fryderyka Kallaya. Kallay był kierownikiem działu ciesielstwa zakopiańskiej szkoły. Należy w tym miejscu wspomnieć, że po stronie węgierskiej (obecnie słowackiej) Tatr budownictwo w stylu tyrolskim było powszechne. Stanisław Witkiewicz ostrzegał m.in. w swej opowieści Na przetęczy: 
"C.k. szkoła fachowa dla drzewnego przemysłu", jest też w Zakopanem rozsadnikiem tyrolsko-wiedeńskiego gustu, niemieckiej trucizny, zabijajq̨cej artyzm góralskiego ludu.

Nie źle prowadzona pod względem fachowym, odznacza się ona nadzwyczajnym brakiem pomysłowości i inicyatywy [...].

Wprowadzajqc formy niemieckie, renesansowe, a często bardzo niefortunne pomysły ozdób, zrywa w swoich uczniach tradycyq naiwnych, szczerych, narodowych upodobań i pozbawia ich łączności z potrzebami najbliższej im sfery ${ }^{14}$.

Warto pamiętać, że gdyby nie działalność Stanisława Witkiewicza i jego walka o oblicze stylu zakopiańskiego Zakopane i w ogóle prawdopodobnie całe Podhale wyglądałoby dziś zupełnie inaczej.

Styl zakopiański został oficjalnie uznany w C.K. Szkole Zawodowej Przemysłu Drzewnego w wyniku nieco anegdotycznego zbiegu zdarzeń. Arcyksiążę Rudolf został zaproszony przez hr. Artura Potockiego do dóbr na granicy Bukowiny. Domek myśliwski hrabiego wyposażony był w meble wykonane w stylu zakopiańskim (według rysunków panny Andrzeykowiczówny). Meble te spodobały się austriackiemu dygnitarzowi do tego stopnia, jak pisał Stanisław Eljasz Radzikowski w swojej książce Styl zakopiański, „[...] że za powrotem do Wiednia zwrócił na nie uwagę ministerstwu. Ministerstwo też nie omieszkało dać wówczas zarządowi szkoły w Zakopanem odpowiedniej instrukcyi, a zatem poszło, że styl zakopiański został przecież raz w szkole urzędownie uznany"15. Spór jednak trwał nadal. W 1901 r., kiedy Kovàts wykładał na Politechnice Lwowskiej, doszło do ogólnokrajowego sporu pomiędzy zwolennikami stylu zakopiańskiego w wersji Witkiewiczowskiej i sposobu zakopańskiego (lub sposobu zakopiańskiego), którego orędownikiem był Kovàts. Warto przypomnieć, że po stronie Kovàtsa wypowiedzieli się m.in. Jan Sas-Zubrzycki i Władysław Jarocki. Witkiewicza poparli Jan Gwalbert Pawlikowski i Feliks Jasieński. Ostatecznie jednak w perspektywie historii w sporze zdecydowanie zwyciężyła koncepcja stylu zakopiańskiego Stanisława Witkiewicza.

\section{PRZYPISY}

1 K. Kwiatkowski, Styl zakopiański Stanisława Witkiewicza i jego differentia specifica, Przestrzeń/ Urbanistyka/Architektura, 1/2020, s. 57-66.

2 Pisze na ten temat Zdzisława Tołłoczko w artykule Zabytek - dzieło sztuki czy tylko świadek historii? Z dziejów neoromanizmu na ziemiach polskich na przykładzie zamku cesarskiego w Poznaniu, „Wiadomości Konserwatorskie”, 37/2014, s. 10.

3 Tamże, s. 12.

4 J. Sas-Zubrzycki, Styl nadwiślański jako odcień sztuki średniowiecznej w Polsce, Volumina.pl, Szczecin 2012 [reprint na podst. wydania oryginalnego: Kraków 1910], s. 138.

5 Tamże. 
6 Próbę opisania metodologii Jana Sasa-Zubrzyckiego zawarłem pierwotnie w: Budowle stylu nadwiślańskiego jako implanty pamięci intencjonalnej. Aspekty urbanistyczne, [w:] Implanty pamięci społecznej. Teoria i przykłady, red. nauk. D. Gortych, Ł. Skoczylas, Wydawnictwo Rys, Poznań 2017, s. 121-142.

7 J. Sas-Zubrzycki, Styl nadwiślański..., dz. cyt., s. 102.

8 Tamże, s. 147.

9 Tamże, s. 171.

10 Tamże, s. 66.

11 Tamże, s. 112.

12 Tamże, s. 34.

13 Tamże, s. 8.

14 S. Witkiewicz, Na przełęczy. Wrażenia i obrazy z Tatr, Gebethner i Wolff, Warszawa 1891, s. 23.

15 S.E. Radzikowski, Styl zakopiański, Towarzystwo Wydawnicze we Lwowie, Kraków 1901, s. 19.

\section{BIBLIOGRAFIA}

Kwiatkowski K., Budowle stylu nadwiślańskiego jako implanty pamięci intencjonalnej. Aspekty urbanistyczne, [w:] Implanty pamięci społecznej. Teoria i przykłady, red. nauk. D. Gortych, Ł. Skoczylas, Wydawnictwo Rys, Poznań 2017, s. 121-142.

K. Kwiatkowski, Styl zakopiański Stanisława Witkiewicza i jego differentia specifica, Przestrzeń/ Urbanistyka/Architektura, 1/2020, s. 57-66.

Radzikowski S.E., Styl zakopiański, Towarzystwo Wydawnicze we Lwowie, Kraków 1901.

Sas-Zubrzycki J., Styl nadwiślański jako odcień sztuki średniowiecznej w Polsce, Volumina.pl, Szczecin 2012 [reprint na podst. wydania oryginalnego: Kraków 1910].

Sas-Zubrzycki J., Skarb architektury w Polsce, t. I-IV, Volumina.pl, Szczecin 2015 [reprint na podst. wydania oryginalnego: Kraków 1907-1909].

Schwechten F., Das Neue Romanische Haus, „Berliner Architekturwelt. Zeitschrift für Baukunst, Malerei, Plastik und Gegenwart", Vierter Jahrgang, 1902, s. 193-204, [online] https:// ia600800.us.archive.org/3/items/berlinerarchitek04vere/berlinerarchitek04vere.pdf (dostęp: 04.06.2019).

Stefański K., Polska architektura sakralna w poszukiwaniu stylu narodowego, Wydawnictwo Uniwersytetu Łódzkiego, Łódź 2000.

Tołłoczko Z., Zabytek - dzieło sztuki czy tylko świadek historii? Z dziejów neoromanizmu na ziemiach polskich na przykładzie zamku cesarskiego w Poznaniu, „Wiadomości Konserwatorskie", 37/2014, s. 7-16.

Tondos B., Styl zakopiański i zakopiańszczyzna, Zakład Narodowy im. Ossolińskich, Wrocław 2009. Witkiewicz S., Na przełęczy. Wrażenia i obrazy z Tatr, Gebethner i Wolff, Warszawa 1891.

Wowczak J., Jan Sas-Zubrzycki. Architekt, historyk i teoretyk architektury, Towarzystwo Wydawnicze „Historia lagellonica”, Kraków 2017. 